Zenner (J. K.). Zur syrischen Lexikographie.

Fraenkel (S.). Bemerkungen zu den jüdisch-persischen Glossen zum Buche Samuel.

Grimme (H.). Abriss der biblisch-hebräischen Metrik.

Nestle (E.). Zu den Codices Sinaitici.

Alberts (0.). Zur Text-kritik des Kudatku Bilik.

II. Viensia Oriental Journat. Vol. xi, No. 4.

Leumann (E.). A list of the Strassburg Collection of Digambara Manuscripts.

Steinschneider (M.). Heilmittelnamen der Araber.

De Harlez (C.). Le livre de diamant clair, lumineux faisant passer à l'autre vie. Traduction du texte mandchou.

Bittner(M.). Türkische Volkslieder. Nach Aufzeichnungen von Schahen Efendi Alan.

III. Journal Asiatique. Série 9, Tome x, No. 3.

Motylinski (A. C. de). Dialogue et textes en berbère de Djerba.

Lambert (Mayer). De l'accent en arabe.

Une inscription phénicienne à Avignon.

Berger (P.). Note sur le même sujet.

Schwab (M.). Transcription de mots grecs et latins en hébreu aux premiers siècles de $J$. $C$.

Devéria (G.). Musulmans et Manichéens chinois.

\title{
III. Notes and News.
}

Objects of the Societr.-The first clause of the Rules of the Society states that it "is instituted for the purpose of investigating the Arts, the History, and the Literature of Asia; and of facilitating intercourse with Eastern peoples by an accurate interpretation of their customs, their feelings, and their beliefs."

This work-as full of practical importance as it is of intellectual interest-is constantly hampered at every turn by the want of funds. 
The Society's Journal, which used to appear sporadically, at intervals sometimes of more than a year, is now issued regularly every quarter. But its size, and the number, therefore, of the subjects which it can treat, is limited by the Society's income; and no further improvements are possible without an increased revenue.

The important series of translations of Eastern books, revived under the name of the "Oriental Translation Fund, New Series," is progressing (thanks to the generosity of one or two individuals). But the proportion of work done to that left undone is still insignificant, owing solely to the want of funds.

An important new series of works dealing with the results to be drawn from such translations, and to be called "Asiatic Studies"-a series withont which the full benefit of the translations cannot be made generally available-is still only a hope, and not an acconplished fact-again from want of funds.

Papers of interest, necessarily excluded from our present Journal on account of length, would appear in such a series. And there also attention could be paid to the important results of Egyptological and Assyriological studies, and to all the immense literature of the Far East. The importance of these branches of Asiatic study is beyond question. But the systematic pursuit, in this Society, of such studies is also stopped for want of funds.

Application having been made for a form of words by which sums of money could be left to the Society for the carrying out of these and similar objects, the following clause has been drawn up:-

\section{FORM OF BEQUEST.}

I give and bequeath to the Royal Asiatic Society of Great Britain and Ireland, of 22, Albemarle Street, London, the sum of $£$

${ }^{1}$ to be applied at the discretion of the Council for

1 If it be necessary to provide ont of the same sum for any person dependent on the testator the following words must be here inserted: "the annual income thereof to be paid during his (or her) life to (or her) decease the suid sum . . . ." and after his 
the time being of the said Society, for the purpose of carrying out any of the objects specified in Clause 1 of the Rules of the Society, or otherwise aiding and extending the work in such manner as the Council shall think fit. The said sum shall be paid out of such part of my Estate as shall be legally applicable for this purpose, and the receipt of the Treasurer of the Society shall be a sufficient discharge for the same.

Guld Medal.-In addition to the sum of $£ 8213 s$. $6 d$. already announced, the following further donations have been received :-

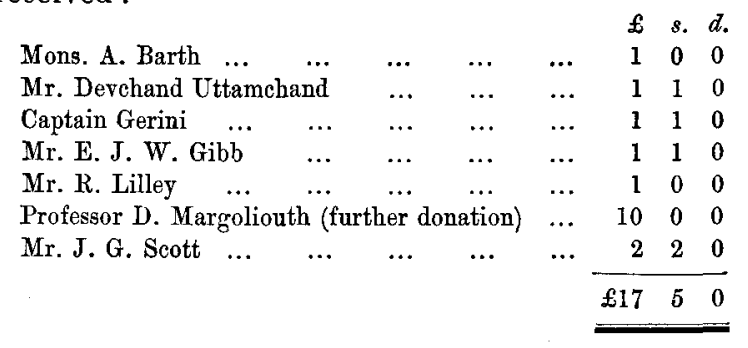

Birdpur Ruins.-Another discovery, which may prove to be of great interest to students of Buddhist history, has been made within the last few days on the Birdpur estate, Basti district. A stupa situated at the twentieth mile on the Uska Nepal Road has been excavated, and after digging down 18 feet of solid brickwork set in clay, a huge stone chest $4 \mathrm{ft}$. $4 \mathrm{in}$. by $2 \mathrm{ft}$. $8 \mathrm{in}$. by $2 \mathrm{ft}$. $1 \frac{1}{2}$ in. was unearthed. The lid was broken in four pieces, and the box was completely closed and embedded in solid brickwork; it was in perfect preservation, and measured inside $36 \mathrm{in}$. by $18 \frac{1}{2}$ in. by $22 \frac{3}{4}$ in. On removing the lid the following articles were revealed:-two small marble vases, with lids, eight inches high and four and a half inches in diameter; one ordinary lota-shaped marble vessel; one small round marble box; and one crystal bowl with cover, the handle of which was a hollow fish filled with gold. All these vessels contained ornaments and relics, consisting of pearls, gold leaf stars, gold leaf stamped with figures, gold, and gold ornaments, stars and other shapes cut in garnets, 
amethyst, topaz, cornelian, etc. They also contained crystals and beads and quantities of small bones in good preservation. No coins were found, and the only inscription was round the lid of one of the bowls, the lettering being the same as that on the Lumbani Garden pillar commemorating the birthplace of Buddha. It seems, from a cursory rendering of this inscription by qualified experts, that these ornaments and relics may have belonged to Buddha himself.-Pioneer. [For the inscription, see Hofrath Dr. Bühler's letter in this month's correspondence.]

Dr. Stein in Buner.-The Pioneer has the following notice:- "Though the short duration of the operations in Buner had restricted very much the range of archaeological exploration, Dr. Stein was able to trace and survey a considerable number of ancient sites and structures in those parts of the country which had temporarily become accessible. Rock-cut sculpture of early date, representing Hindu deities, were found in two localities at the foot of spurs descending from Mount Ilm. They show that the Buddhist faith, which had, according to historical evidence, been prevalent in these regions for a long period previous to the Muhammadan conquest, was here, as elsewhere in India, closely associated with all popular features of the Hindu religious system. In connection herewith it is perhaps of interest to note that inquiries have shown Mount Ilm to be still a popular place of pilgrimage for the Hindus resident in Buner and Swat. The Tirthas visited by the pilgrims are situated close to the top of this fine mountain, which dominates the landscape in northern Buner. Unfortunately they were too far to be reached within the available time from the nearest camps of the 1st Brigade at Juwar and Padshah. Remains of stupa mounds were found not far from the latter place and at Girarai. But the more numerous and important ruins of this kind are situated in the main valley of Buner, that of the Barandu River. From Bampokha down to Bajkatta in the east a series of such ruins was traced, which can be 
attributed with great probability to Buddhist monasteries. Conspicuous among them are the remains of a great stupa and attached sangharama a short distance below Tursak, the chief place of modern Buner. A short trial excavation conducted here with the assistance of a small party of sappers brought to light a corner of the stucco-ornamented stupabase, and showed the great depth to which the original level of the chapel court had been covered up by the masses of débris. Weeks of work would be required for the proper clearing of this and similar sites. That Tursak was an important place also in old times, is made evident by the numerous ruins of fortified dwelling-places close to it on the heights of the Jaffar Hill, Another place of importance for the ancient topography of Buner is undoubtedly the site of the present Sunigram. This village, which bears an old Hindu name, occupies a conspicuous position on the Barandu River, where it enters the broad open portion of the valley known as Panjpau. To the south of the village stands a high mound of solid masonry which belonged to a stupa of at least 150 feet diameter. On a rocky ridge above the village and overlooking the valley are the comparatively well-preserved ruins of a large monastery, built on walled-up terraces of great extent. The walls and vaulted roofs of the several halls are of remarkably strong construction, and have stood the test of time and other destructive agencies better than any other old buildings examined in Buner. Unfortunately treasure-seekers seem to have been at work here too. The stupa in front of the monastery has been dug into long ago, evidently for the sake of the relics deposited below it. This has also been the fate of the fine stupa which stands a short distance to the east of Sunigram, near the village of Takhtaband, and still reaches to a height of over 50 feet. A broad cutting has been made to the centre of this solid mass of masonry and through its whole height. It is probable that some of the ruined structures now examined for the first time are to be identified with the several sacred sites mentioned by the Chinese pilgrims at some distance 
to the south of the old Swat capital, Mungali, the present Manglaur. The survey now made of them will thus help to establish with greater certainty the ancient topography of the regions once comprised in Udyana. The readiness shown by the several tribal sections in complying with the Government terms after the fight on the Tanga Pass had its advantage from an antiquarian point of view, inasmuch as it permitted Dr. Stein to visit with a small escort localities comparatively far away from the routes taken by the troops. But it is also responsible for the rapid examination of the country, which restricted with the narrowest limits the time allowed for archaeological search. Mount Mahaban, which, owing to its possible identity with Alexander's Aornos, represents an object of special interest, seemed temptingly near, yet remained entirely outside the sphere opened up by the expedition. A rapid ride down the Chamla Valley as far as Kuria made it possible at least to collect reliable information about the old ruined fortifications, known by the name of Shah Kot, which crown the summit of the mountain. Whether they were built to enclose a Buddhist shrine like that within the walls of Ranigat hill, or reach back to a still earlier period, remains uncertain."

Discovery of Early Budphist Remains.-Major Deane has made a very interesting find. In Chapter iii of Huan Thsang's Travels he states (Julien, 1. 135; Beal, 1. 123), in his description of Udyāna, that $30 l i$ from the spring of Apalāla, and north of the river Subhavastu (=Swät), there was on a rock a representation of the Buddha's footprints. Searching for this, Major Deane found footprints graven on a rock half a mile south of the village Tirath, on the boundary of the Swāt valley, with inscriptions beneath. Hofrath Dr. Bühler, to whom photographs have been sent, reads the Kharosthi letters of the inscription, which he would assign to the first century B.C., as Bodhassa Sakamunisa padāni, "the footprints of the Buddha Śakya-muni." The Chinese pilgrim mentions a house, or shed, built over the 
impression of the sacred feet. There is apparently no sign of this building left. -Another old Kharoṣthī inscription has also been found in a spring or well about eight miles south of Attock, recording the name of the man who dug it out in the reign of Huvișka. Hofrath Dr. Bühler has dealt with all these in a paper in the Anzeiger der philosophischhistorischen Classe at Vienna for February, 1898.

Paris International Congress of Orientalists.-The proceedings of this Congress are being pushed on, and it is expected that two volumes will be ready for distribution to the members in June, and the third at the end of this year.

Orientai، Congress.-The Twelfth International Congress of Orientalists will be held in Rome from the 2nd to the 12th of October, 1899. All communications as to papers or membership should be addressed to Le Comte A. de Gubernatis, Via San Martino al Macao 11, Rome, or Le Comte Francesco Pullé, Via Giordani 7, Florence.

\section{Angana again.}

Mr. Beames writes to say that angan, or some slightly modified form of it, is now used in all the modern Aryan vernaculars of India for the space inside the four sides of the square round which the native houses are usually built. Other terms are also in use, such as uthän in Bengali and sahan among Muhammadans, etc. But the word angan in this sense is familiar from Calcutta to Peshawar. As to the meaning, he would venture to suggest that as the Sanskrit root ang means 'to walk about, or roam,' angana might well mean in the primary, concrete, sense 'a place to walk in'; and in the secondary, ethical, sense 'straying (from the right path), erring.' Anangana, ' unerring,' would be an appropriate epithet for an Arahat. In the words from the Candrapradipa Sūtra samädhim labhati niranganam would then mean ' he attains undisturbed (i.e. not wandering) meditation.' 
I am very glad my few remarks have attracted the attention of so distinguished a scholar, and I do not think that there is much, if any, difference between us. Courtyard conveys in England the idea of a small space, enclosed (probably by walls), and paved. When we read, in an author of the fifth century A.D., of a king on the march with his army pitching his camp-that is, for the whole army -in an aygana, it is clear that the word cannot possibly have meant 'courtyard' at that time. When we read of a man seeking a secluded spot to repeat a magic formula, which he is keenly anxious no one should hear, and choosing for that purpose an aygana, and an aygana in a forest, it is equally clear that, when the author of that passage wrote, the word could not have had the sense which angan now has in the vernaculars of India. And I venture to think that ' courtyard' is by no means a happy rendering of aygan, or its modifications, even in the modern sense.

But is the modern angan a direct descendant of angana? In all the old texts we have the cerebral $n$, not the dental $n$. It is true that the texts are in an old Prakrit, and some Prakrits frequently change the dental to cerebral. But the Pāli does so only in certain well-known cases, of which the present is not one. We have now quite enough Pāli texts to enable us to speak with certainty on the point, and the immense number of derivatives in -ana have all retained the dental. The form is therefore so familiar in Palli that it is most difficult to explain how, if the word had once ended in -ana, it could have been changed, against all analogy, to $-a n a$; and I think we must conclude that, if the two words are related, the original form was ayguna, not aygana, and in any case that the word I was discussing was so spelt.

There is no mention, or suggestion, in any of the old passages where the word occurs, either of a group of onestoried buildings round an open square space, or of any paving, or of smearing with cow-dung. Nor is any passage known to me in the old texts where the common modern 
form of an Indian peasant's dwelling must be inferred as having been common also in those times. When did that form of dwelling, ranged round a square or oblong space, become prevalent? Whenever it did the occupiers might very naturally have applied to the space inside the word they had previously used for the space outside. And that may be the connection between the ancient aygana and the modern angan or its modifications. But there may be no connection at all; and in any case the derivation of aygana seems to me still quite uncertain.

RH. D.

\section{Additions to the Library.}

Presented by T. Watters, Esq.

Le père Etienne Zi. Pratique des examens littéraires en Chine.

8vo. Chang-Hai, 1894.

A Collection of Dhāranis translated in Sanskrit, Chinese, and Korean.

A Tibetan translation of the Vajrachedika. (Peking.)

A Tibetan translation of the Saddharma-pundarika. (Peking.)

Chu-t'i-hsin-Ching. The Mahāprajñaparamitāhridaya sūtra transcribed in various styles of Chinese writing, headed by two Sanskrit characters maha. The name of each specimen of writing is given at the head, and a few particulurs are added below. (Japanese.)

Siddhamāta-t'i-wên. A Sanskrit-Chinese Primer.

Siddham-san-mi-ch'ao, in seven vols. A book on the Sanskrit alphabet and its combinations. (Japan.)

Hsi-t'an-tzŭ-chi. A Siddham of the T'ang Period, in ten sections.

From the India Office.

Bhandarkar (R. G.). Report on the Search for Sanskrit MSS. in the Bombay Presidency during 1887-881890-91. 8vo. Bombay, 1897. 